УДК $581.52+582.475+(235.222)$

\title{
Structure of Forests and Climatic Response of Trees in "Forest-Steppe" Contact Zone, the Altai Mountains
}

\author{
Anatoly Yu. Bocharov* and Dmitry A. Savchuk \\ Institute of Monitoring of Climatic and Ecological Systems SB RAS \\ 10/3 Academichesky prospekt, Tomsk, 634055, Russia
}

Received 15.04.2015, received in revised form 17.06.2015, accepted 29.08.2015

\begin{abstract}
Age structure of forests and radial increment of conifers were studied in the "forest-steppe" contact zone: Siberian stone pine-Siberian spruce-Siberian larch forest in the lower belt of Severo-Chuisky Range, Siberian larch-Siberian spruce-Siberian stone pine forest at the forest-steppe boundary and Siberian larch forests in the forest-steppe ecotone in Kuraiskaya steppe (the Altai Mountains). The structure of the coniferous forests is complex with three generations along the transect: the lower forest belt $->$ forest-steppe boundary $\rightarrow>$ forest-steppe ecotone. Percentage of larch trees increases from the forest belt to the steppe. The larch tree ring width chronologies are synchronous but different by their amplitudes. In the modern warming period the radial increment of larch limits by precipitation deficit and high air temperature during the vegetation period at the forest-steppe boundary. The generations appearance relates to century and intra-century cycles of the climate warming.
\end{abstract}

Keywords: age structure, tree ring width, dendroclimatology, Siberian larch, Siberian stone pine, Altai Mountains.

DOI: 10.17516/1997-1389-2015-8-4-426-440.

(C) Siberian Federal University. All rights reserved

* Corresponding author E-mail address: bochar74@mail.ru 


\title{
Структура лесов и климатический отклик деревьев в зоне контакта «лес-степь» (Горный Алтай)
}

\author{
А.Ю. Бочаров, Д.А. Савчук \\ Институт мониторинга климатических и экологических систем СО РАН \\ Россия, 634055, Томск, пр. Академический, 10/3
}

\begin{abstract}
Изучение радиального прироста деревьев и возрастного строения лесов позволяет проследить формирование лесных экосистем, охарактеризовать темпы и особенности их развития в условиях изменений климата. Исследования возрастной структуры лесов и климатически обусловленной изменчивости радиального прироста хвойных деревьев проводились в зоне контакта «лес-степь» на северном макросклоне Северо-Чуйского хребта и Курайской степи (Горный Алтай): в кедрово-елово-лиственничных лесах в нижней части лесного пояса, в лиственнично-кедрово-еловых лесах на лесостепной границе и чистых лиственничниках в лесостепном экотоне. Структура хвойных лесов на нижней климатической границе их распространения (по высотному профилю: нижняя часть лесного пояса $\rightarrow>$ лесостепная граница -> лесостепной экотон) сложная, циклично-разновозрастная, с тремя возрастными поколениями. При движении вдоль профиля (от леса к степи) доля участия лиственницы в составе насаждений увеличивается. Полученные локальные хронологии радиального прироста лиственницы по высотному профилю хорошо согласуются между собой, но различаются по амплитуде. В современный период потепления климата радиальный прирост лиственнищы на лесостепной границе и в лесостепном экотоне лимитируется недостатком осадков и высокой температурой воздуха в течение вегетационного периода. Появление возрастных поколений в насаждениях связано с вековой и внутривековой ичикличностью потепления климата.
\end{abstract}

Ключевые слова: возрастная структура, дендроклиматология, радиальный прирост, лиственница сибирская, кедр сибирский, Горный Алтай.

\section{Введение}

Годичные кольца деревьев позволяют точно определить возраст деревьев и изучить динамику изменения прироста древесины. Исследования радиального прироста хвойных в зоне контакта «лес-степь» проводились на лиственнице (Kucherov, 2010; Магда и др., 2011), сосне (Магда, Зеленова, 2002; Сафронов, Гурский, 2005; Agafonov, Kukarskikh, 2008; Вахнина, 2011; Малышева, Быков, 2011а, 2011б; Матвеев и др., 2012а), ели финской и сосне при их совместном произрастании (Тишин, 2008) и др. При этом выявлено как пре- обладающее влияние осадков на динамику прироста (Матвеев и др., $2012 б$ и др.), так и совместное воздействие на нее температуры и осадков (Глызин и др., 2005; Магда, Ваганов, 2006; Магда и др., 2011). В то же время изучение радиального прироста деревьев вместе с таксационным и, в частности, возрастным строением лесов с учетом существующих закономерностей хода роста древостоев позволяет проследить формирование лесных экосистем, охарактеризовать темпы и особенности их развития в условиях климатических изменений. 
Цель работы - проанализировать таксационную, в том числе возрастную, структуру древостоев в зоне контакта древесной растительности нижней части лесного пояса Северо-Чуйского хребта и Курайской степи (Горный Алтай) в циклах похолодания и потепления климата, построить древеснокольцевые хронологии лиственницы, кедра и ели и выявить связи их прироста с климатическими переменными.

\section{Материалы и методы исследований}

Исследования структуры хвойных древостоев и радиального роста кедра сибирского (Pinus sibirica Du Tour), лиственницы сибирской (Larix sibirica Ledeb.) и ели сибирской (Pícea obovata Ledeb.) проводили в зоне контакта леса Северо-Чуйского хребта и Курайской степи (Горный Алтай) летом 2010 г.: в нижней части лесного пояса на северном макросклоне хребта, на лесостепной границе и лесостепном экотоне. Здесь были заложены пять постоянных пробных площадей (ПП) (по высотному профилю: нижняя часть лесного пояса (ПП1) -> лесостепная граница (ПП2 и 3) -> лесостепной экотон (ПП4 и 5)) на высотах 1650-1750 м над ур. м. (табл. 1). Исследования в нижней части лесного пояса выполняли в сомкнутом лесу, на лесостепной границе - в пограничной полосе шириной 100-200 м между сомкнутыми лесами и степью, в лесостепном экотоне - в сомкнутых изолированных друг от друга лесных фрагментах, расположенных в степи (рис. 1). Курайская степь,

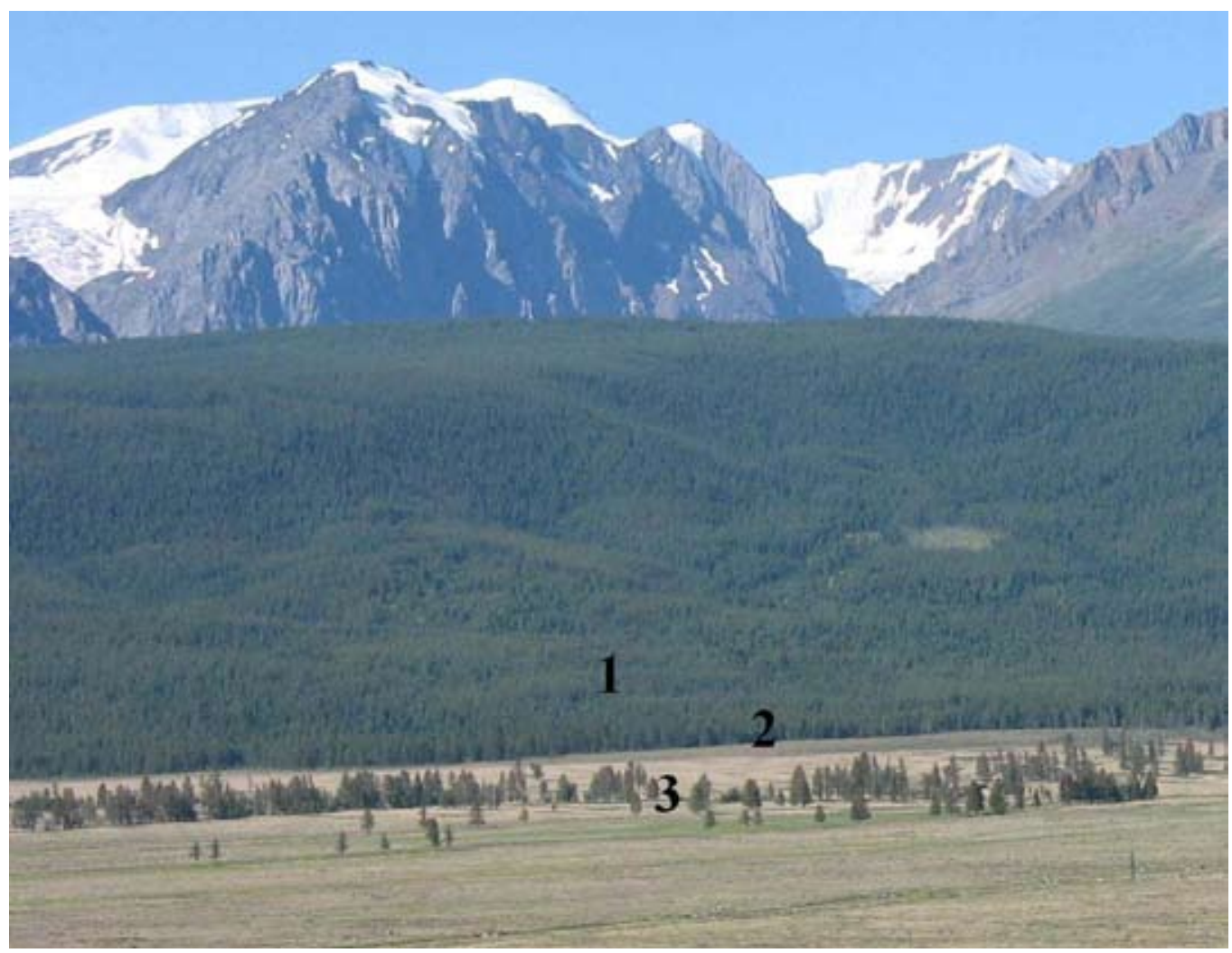

Рис. 1. Район исследований в зоне контакта древесной растительности в нижней части лесного пояса Северо-Чуйского хребта и Курайской степи (Горный Алтай) по высотному профилю: нижняя часть лесного пояса (1) -> лесостепная граница (2) -> лесостепной экотон (3). Фотография Е.О. Филимоновой 
Таблица 1. Основные таксационные характеристики пробных площадей в зоне контакта «лес-степь» (Северо-Чуйский хребет, Курайская степь, Горный Алтай)

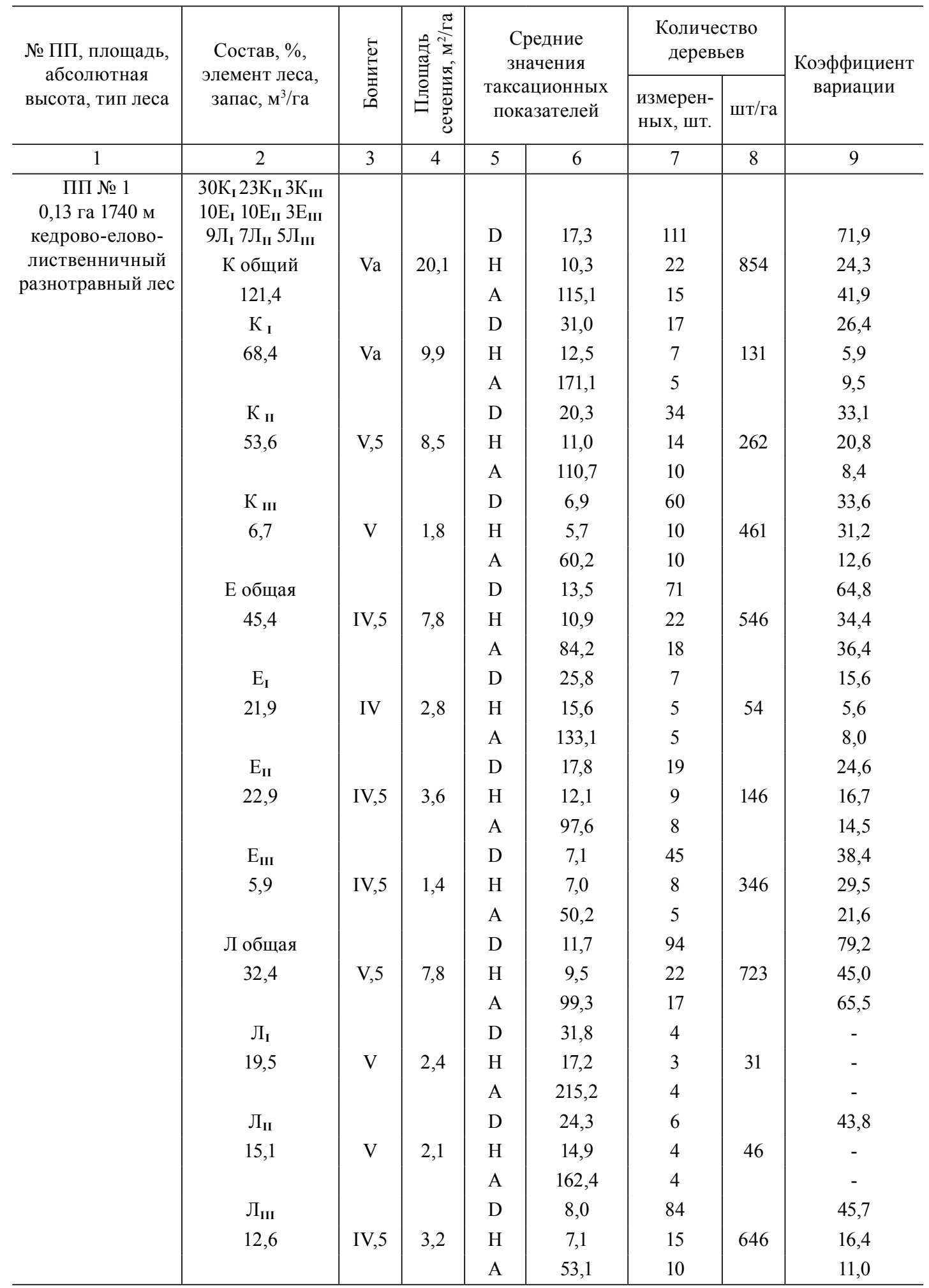


Продолжение табл. 1

\begin{tabular}{|c|c|c|c|c|c|c|c|c|}
\hline 1 & 2 & 3 & 4 & 5 & 6 & 7 & 8 & 9 \\
\hline \multirow{18}{*}{$\begin{array}{c}\text { ПП № } 2 \\
0,14 \text { га } 1720 \text { м } \\
\text { лиственнично- } \\
\text { елово-кедровый } \\
\text { разнотравный лес }\end{array}$} & $\begin{array}{c}6 Л_{I} 66 Л_{I I} 21 Л_{I I I} \\
4 \mathrm{E} 3 K\end{array}$ & \multirow{4}{*}{ V } & \multirow{4}{*}{20,9} & $\mathrm{D}$ & 11,7 & 215 & \multirow{4}{*}{1569} & 51,5 \\
\hline & Л общая & & & $\mathrm{H}$ & 11,6 & 21 & & 16,2 \\
\hline & 121,8 & & & A & 107,8 & 16 & & 46,0 \\
\hline & $Л_{I}$ & & & $\mathrm{D}$ & 26,8 & 3 & & - \\
\hline & \multirow[t]{2}{*}{8,5} & \multirow[t]{3}{*}{ Va } & \multirow[t]{2}{*}{1,2} & $\mathrm{H}$ & 14,5 & 3 & \multirow[t]{3}{*}{22} & - \\
\hline & & & & A & 231,0 & 3 & & - \\
\hline & $Л_{I I}$ & & \multirow{3}{*}{13,9} & $\mathrm{D}$ & 16,1 & 93 & & 22,2 \\
\hline & \multirow[t]{2}{*}{88,1} & \multirow[t]{3}{*}{ V } & & $\mathrm{H}$ & 13,0 & 14 & \multirow[t]{3}{*}{679} & 13,4 \\
\hline & & & & A & 126,0 & 10 & & 16,6 \\
\hline & $Л_{\text {III }}$ & & \multirow{3}{*}{5,8} & $\mathrm{D}$ & 7,7 & 172 & & 33,6 \\
\hline & \multirow[t]{2}{*}{27,7} & \multirow[t]{3}{*}{ III,5 } & & $\mathrm{H}$ & 9,5 & 6 & \multirow[t]{3}{*}{1255} & 13,3 \\
\hline & & & & A & 54,1 & 5 & & 17,6 \\
\hline & E & & \multirow{4}{*}{0,9} & D & 20,0 & 4 & & - \\
\hline & \multirow[t]{2}{*}{5,8} & \multirow[t]{3}{*}{ IV } & & $\mathrm{H}$ & 12,1 & 2 & \multirow[t]{3}{*}{30} & - \\
\hline & & & & A & 78,4 & 3 & & - \\
\hline & K & & & $\mathrm{D}$ & 15,0 & 5 & & 30,4 \\
\hline & 3,6 & \multirow[t]{2}{*}{$\mathrm{V}, 5$} & \multirow[t]{2}{*}{0,6} & $\mathrm{H}$ & 9,2 & 3 & \multirow[t]{3}{*}{37} & - \\
\hline & & & & A & 89,4 & 3 & & - \\
\hline $\begin{array}{c}\text { ПП № } 3 \\
0,1 \text { га } 1700 \text { м }\end{array}$ & $\begin{array}{c}10 Л_{I} 59 Л_{\text {II }} 18 Л_{\text {III }} \\
11 \kappa_{\text {I }} 2 K_{\text {II }} \text { ед. } \mathrm{E}\end{array}$ & & & $\mathrm{D}$ & 13,8 & 106 & & 48,3 \\
\hline лиственнично- & Л общая & V & 15,8 & $\mathrm{H}$ & 10,4 & 28 & 1060 & 32,2 \\
\hline кедровыи & 92,3 & & & A & 96,2 & 10 & & 65,6 \\
\hline & $Л_{I}$ & & & $\mathrm{D}$ & 24,9 & 4 & & - \\
\hline & 10,0 & Vб & 1,9 & $\mathrm{H}$ & 9,9 & 3 & 40 & - \\
\hline & & & & A & 238,0 & 2 & & - \\
\hline & $Л_{I I}$ & & & $\mathrm{D}$ & 18,2 & 36 & & 26,5 \\
\hline & 61,3 & III,5 & 9,3 & $\mathrm{H}$ & 13,6 & 17 & 360 & 17,8 \\
\hline & & & & A & 83,2 & 3 & & - \\
\hline & $Л_{\text {III }}$ & & & $\mathrm{D}$ & 9,7 & 66 & & 37,6 \\
\hline & 18,7 & IV,5 & 4,9 & $\mathrm{H}$ & 6,7 & 8 & 660 & 33,2 \\
\hline & & & & A & 54 & 5 & & 15,5 \\
\hline & К общий & & & $\mathrm{D}$ & 11,3 & 13 & & 77,0 \\
\hline & 6,2 & $\mathrm{~V}, 5$ & 1,2 & $\mathrm{H}$ & 8,2 & 7 & 130 & 46,7 \\
\hline & & & & A & 85,9 & 4 & & - \\
\hline & $\mathrm{K}_{\mathrm{I}}$ & & & $\mathrm{D}$ & 26,0 & 3 & & - \\
\hline & 11,9 & V & 1,6 & $\mathrm{H}$ & 13,1 & 3 & 30 & - \\
\hline & & & & A & 127,5 & 2 & & - \\
\hline & $\mathrm{K}_{\mathrm{II}}$ & & & $\mathrm{D}$ & 7,1 & 10 & & 23,9 \\
\hline & 1,5 & $\mathrm{~V}, 5$ & 0,4 & $\mathrm{H}$ & 5,5 & 4 & 100 & - \\
\hline & & & & A & 58,2 & 2 & & - \\
\hline & Е общая & & & D & 13,4 & 1 & & - \\
\hline & 0,8 & III,5 & 0,1 & $\mathrm{H}$ & 10,2 & 1 & 10 & - \\
\hline & & & & A & 54,0 & 1 & & - \\
\hline
\end{tabular}


Окончание табл. 1

\begin{tabular}{|c|c|c|c|c|c|c|c|c|}
\hline 1 & 2 & 3 & 4 & 5 & 6 & 7 & 8 & 9 \\
\hline \multirow{12}{*}{$\begin{array}{c}\text { ПП № } 4 \\
\text { 0,008 га } 1665 \text { м } \\
\text { лиственничный } \\
\text { мелкотравный } \\
\text { лес }\end{array}$} & $24 Л_{I} 46 Л_{I I} 30 Л_{I I I}$ & \multirow{4}{*}{$\mathrm{Va}$} & \multirow{4}{*}{98,1} & D & 20,4 & 24 & \multirow{4}{*}{3000} & 52,5 \\
\hline & Л общая & & & $\mathrm{H}$ & 13,3 & 22 & & 41,3 \\
\hline & 634,9 & & & A & 195,5 & 14 & & 43,3 \\
\hline & $Л_{I}$ & & & $\mathrm{D}$ & 37,5 & 2 & & - \\
\hline & \multirow[t]{2}{*}{231,8} & \multirow[t]{3}{*}{ V } & \multirow[t]{2}{*}{27,6} & $\mathrm{H}$ & 18,3 & 2 & \multirow[t]{3}{*}{250} & - \\
\hline & & & & A & 265,0 & 2 & & - \\
\hline & $Л_{I I}$ & & \multirow{4}{*}{69,5} & $\mathrm{D}$ & 19,8 & 18 & & 32,5 \\
\hline & \multirow[t]{2}{*}{442,7} & \multirow[t]{3}{*}{$\mathrm{Va}$} & & $\mathrm{H}$ & 13,0 & 16 & \multirow[t]{3}{*}{2250} & 24,7 \\
\hline & & & & A & 189,3 & 8 & & 9,2 \\
\hline & $Л_{\text {III }}$ & & & $\mathrm{D}$ & 5,2 & 4 & & - \\
\hline & 2,9 & \multirow[t]{2}{*}{$\mathrm{Va}, 5$} & \multirow[t]{2}{*}{1,1} & $\mathrm{H}$ & 4,3 & 4 & \multirow[t]{2}{*}{500} & - \\
\hline & & & & A & 68,8 & 4 & & - \\
\hline \multirow{9}{*}{$\begin{array}{c}\text { ПП № } 5 \\
\text { 0,012 га } 1665 \text { м } \\
\text { лиственничный } \\
\text { мелкотравный } \\
\text { лес }\end{array}$} & $51 Л_{I} 49 Л_{I I}$ & \multirow{4}{*}{ IV,5 } & \multirow{4}{*}{69,0} & $\mathrm{D}$ & 15,0 & 46 & \multirow{4}{*}{3931} & 82,9 \\
\hline & Л общая & & & $\mathrm{H}$ & 9,8 & 46 & & 62,7 \\
\hline & 350,1 & & & A & 75,3 & 18 & & 55,3 \\
\hline & $Л_{I}$ & & & $\mathrm{D}$ & 35,9 & 3 & & - \\
\hline & \multirow[t]{2}{*}{193,1} & \multirow[t]{3}{*}{ V } & \multirow[t]{2}{*}{25,9} & $\mathrm{H}$ & 16,0 & 3 & \multirow[t]{3}{*}{256} & - \\
\hline & & & & A & 184,3 & 3 & & - \\
\hline & $Л_{I I}$ & & \multirow{3}{*}{43,1} & D & 12,2 & 43 & & 73,9 \\
\hline & \multirow[t]{2}{*}{183,3} & \multirow[t]{2}{*}{ V } & & $\mathrm{H}$ & 8,3 & 43 & \multirow[t]{2}{*}{3675} & 60,4 \\
\hline & & & & A & 73,4 & 15 & & 30,0 \\
\hline
\end{tabular}

Примечание. D - диаметр на уровне груди, см, Н - высота, м, А - возраст, лет.

на границе с которой проводили исследования, - одна из самых засушливых территорий Алтая: сумма осадков за год здесь составляет 200 мм (Харламова, Козлова, 2014).

Заложение пробных площадей осуществлялось с учетом существующих рекомендаций (ОСТ, 1984): шел сплошной перечет деревьев по возрастным поколениям, измерялись высоты и диаметры деревьев, подсчитывался подрост. Вся дальнейшая обработка материала велась по выделенным поколениям и по древостою в целом. Разбиение древостоев на возрастные категории (поколения) и определение типов их возрастной структуры производилось по классификации И.В. Семечкина (1970) с учетом значений коэффициента вариации для возрастного распределения деревьев. Образцами для анализа возрастной структуры и радиального прироста служили керны по двум радиусам, взятые с помощью возрастного бурава, преимущественно по каждой ступени толщины, и отдельно по возрастным поколениям. Для деревьев с сердцевинной гнилью вносилась возрастная поправка на величину гнили (Семечкина, 1964). Общее количество модельных деревьев лиственницы, кедра и ели, с которых отбирались керны, составило 126, 40 и 36 соответственно, по поколениям - от 30 до 100 \% деревьев в зависимости от их представленности в возрастном поколении.

Для построения древесно-кольцевых хронологий измерялась ширина древесных колец с помощью измерительного комплекса LINTAB c пакетом компьютерных программ TSAP (Rinn, 1996) с точностью 0,01 мм. После полу- 
чения индивидуальных древесно-кольцевых рядов шло их перекрестное датирование с помощью сочетания кросс-корреляционного анализа (Holmes, 1983) и графической перекрестной датировки (Douglass, 1919). Надежность такого датирования оценивалась расчетом тесноты связи между такими сериями с пошаговым вычислением коэффициента корреляции при помощи программы COFECHA (Holmes, 1992a). Затем проводили стандартизацию серий с оценкой возрастного тренда каждого дерева с помощью сплайн-функции (окно сплайна 67 \% от длины ряда, 50 \%-ный уровень подавления дисперсии), при которой подбираются значения кривой с наименьшим среднеквадратическим отклонением аппроксимации, негативной экспонентой и линейной регрессией. Эта процедура выполнялась с помощью программы CRONOL (Holmes, 1992б). Кроме того, для устранения автокорреляционной составляющей и усиления климатического сигнала индивидуальные ряды индексов моделировались авторегрессионным (AR) (Cook, 1985) процессом или процессом авторегрессии скользящего среднего (ARMA) (Guiot, 1986). Указанная процедура также выполнялась при помощи программы CRONOL (Holmes, 1992б). Индивидуальные индексные серии усреднялись в хронологии. В результате стандартизации получали две серии: стандартную и остаточную. Для каждой хронологии рассчитывались основные статистические характеристики: коэффициенты чувствительности, синхронности, стандартное отклонение.

Для выявления климатического отклика деревьев использовались данные по среднемесячным температурам и суммам осадков ближайшей метеостанции Актру, расположенной в 8-10 км от пробных площадей, заложенных вдоль высотного профиля. Корреляционный анализ остаточных хронологий прироста и рядов климатических переменных выполнялся в специализированном пакете Statistica for Windows.

\section{Результаты исследования и обсуждение}

Анализ таксационной структуры насаждений показал, что древостои сомкнутых лесов нижней части лесного пояса и на лесостепной границе обладают достаточно сложным строением. Они представлены тремя породами, имеют циклично-разновозрастную структуру основного древостоя, состоящую из трех возрастных поколений. Некоторые характеристики исследованных лесных сообществ приведены в табл. 1 .

В нижней части лесного пояса, вблизи поймы р. Актру, на высотах 1720-1750 м преобладают сомкнутые разнотравные кедровоелово-лиственничные насаждения с участием в составе лиственницы до $21 \%$ и ели до $23 \%$ по запасу (рис. 2). Кедровая часть древостоя представлена деревьями трех возрастных поколений. Средний возраст первого (основного) поколения 171 год, наиболее молодого - 60 лет. Высота 12,5 и 5,7 м соответственно. Абсолютная полнота кедровой части 20,1 м²/га, для древостоя в целом - 35,7 м²/га. Бонитет от $\mathrm{V}$ до Va. Лиственничный древостой также состоит из деревьев трех возрастных поколений. Первое и основное по запасу поколение представлено единичными деревьями со средним возрастом 215 лет, высота 17,2 м, второе и третье имеют близкий возраст с первым и третьим поколениями кедра - 162 и 53 года, высота 14,9-7,1 м соответственно. Средний возраст деревьев первого поколения ели 133 года, высота 15,6 м, средний возраст деревьев второго и третьего поколений близок к возрасту кедровой части - 97 и 50 лет, высота 12,1-7,0 м соответственно. Подрост елово-кедровый, общим количеством до 5 тыс. шт/га.

$$
-432-
$$




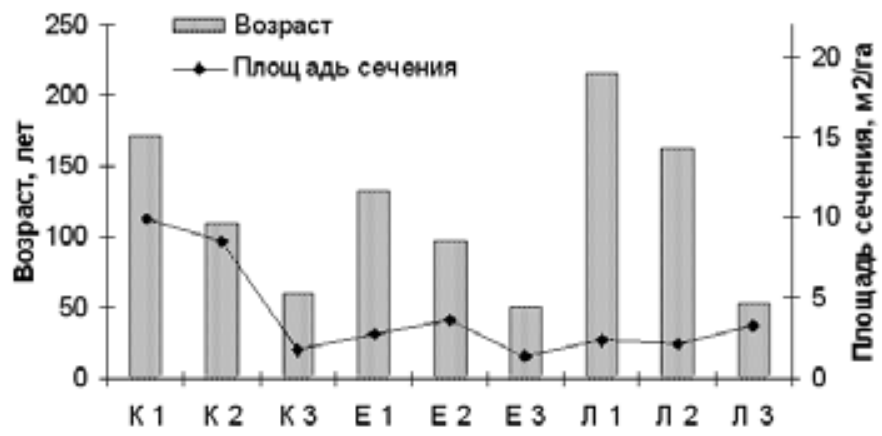

Рис. 2. Возрастная структура и абсолютная полнота возрастных поколений древостоев в нижней части лесного пояса (ПП 1)

A

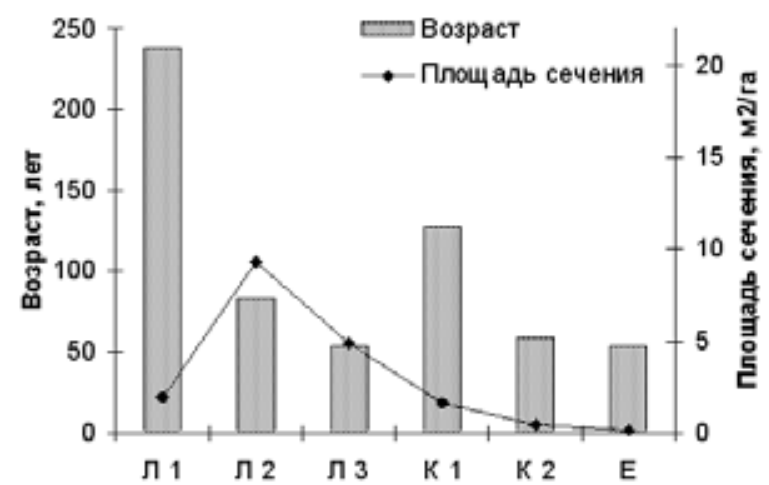

Б

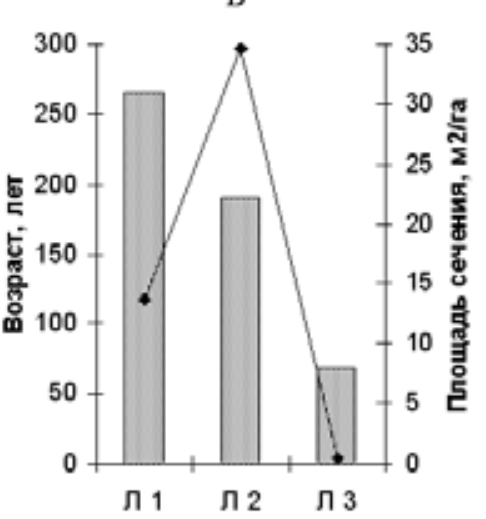

Рис. 3. Возрастная структура и абсолютная полнота возрастных поколений древостоев на лесостепной границе (А) (ПП 3) и в лесостепном экотоне (Б) (ПП 4)

На лесостепной границе (в пограничной полосе шириной 100-200 м между сомкнутыми лесами и степью) распространены разнотравные лиственнично-кедрово-еловые насаждения с участием кедра в составе от 3 до $13 \%$ по запасу. Ель на некоторых участках насаждений может достигать $4 \%$ в составе, но в основном представлена единичными экземплярами 50-60-летнего возраста (рис. 3a). Лиственничная часть древостоя состоит из деревьев трех поколений. Бонитет возрастных групп от III,5 до Vб. Абсолютная полнота лиственницы от 15,8 до 20,9 м²/га, для древостоя в целом - 17,1-22,4 м²/га. Первое поколе- ние представлено единичными деревьями со средним возрастом от 231 до 238 лет. Средняя высота 10-14,5 м. Деревья второго основного поколения имеют средний возраст от 83 лет на границе леса со степью до 126 лет в приграничных участках леса. Возраст наиболее молодого поколения лиственницы по всей границе леса близок и составляет 54 года. Кедровый древостой представлен деревьями одного или двух поколений со средним возрастом основного яруса 89-128 лет и второго - 58 лет. Средняя высота 9,2-13,1 м и 5,5 м соответственно. Бонитет от V до V,5. Абсолютная полнота от 0,6 до 2,0 м²/га. Под- 
рост в основном кедровый, произрастает в окнах древостоя и под кронами деревьев кедра, количеством до 3 тыс. шт/га.

В лесостепном экотоне на высоте 1660 м произрастают изолированные друг от друга лиственничные лесные фрагменты с достаточно высокой полнотой и сомкнутостью. Бонитет от V до Va. Абсолютная полнота до 98,1 м²/га. Данные древостои состоят из деревьев двух, реже трех возрастных поколений (рис. 3б). Первое поколение представлено единичными деревьями со средним возрастом 265 лет и высотой 18,3 м. Второе основное поколение имеет средний возраст от 184 до 189 лет, среднюю высоту 13-16 м. Наиболее молодое третье поколение со средним возрастом деревьев от 69 до 73 лет и высотой 4,3-8,3 м. Отмечен лиственничный подрост количеством до 1 тыс. шт/га.

Таким образом, при движении вниз по высотному профилю от леса к степи возрастная структура древостоев упрощается, а возраст деревьев уменьшается. Описанные зако- номерности возрастной структуры нарушают деревья лиственницы первого поколения (единичные остатки материнского полога). Аналогичное упрощение структуры древостоев при движении к границам произрастания лесов и нарушение этой закономерности лиственницей характерно для Северо-Чуйского и Семинского хребтов (Бочаров, 2011a). Количество подроста также снижается.

Для анализа динамики радиального прироста деревьев вдоль высотного профиля были построены локальные хронологии по кедру, лиственнице и ели (всего 11 хронологий) с максимальной длительностью 166, 157 и 118 лет соответственно (рис. 4). Обобщенные хронологии показали достаточно высокую согласованность между собой внутри каждой породы. Синхронность изменений ширины годичных колец у лиственницы высокая (75 \%), по градации С.Г. Шиятова (1986). Коэффициент чувствительности серий по лиственнице от 0,22 в нижней части лесного пояса до 0,38 в лесостепном экотоне.
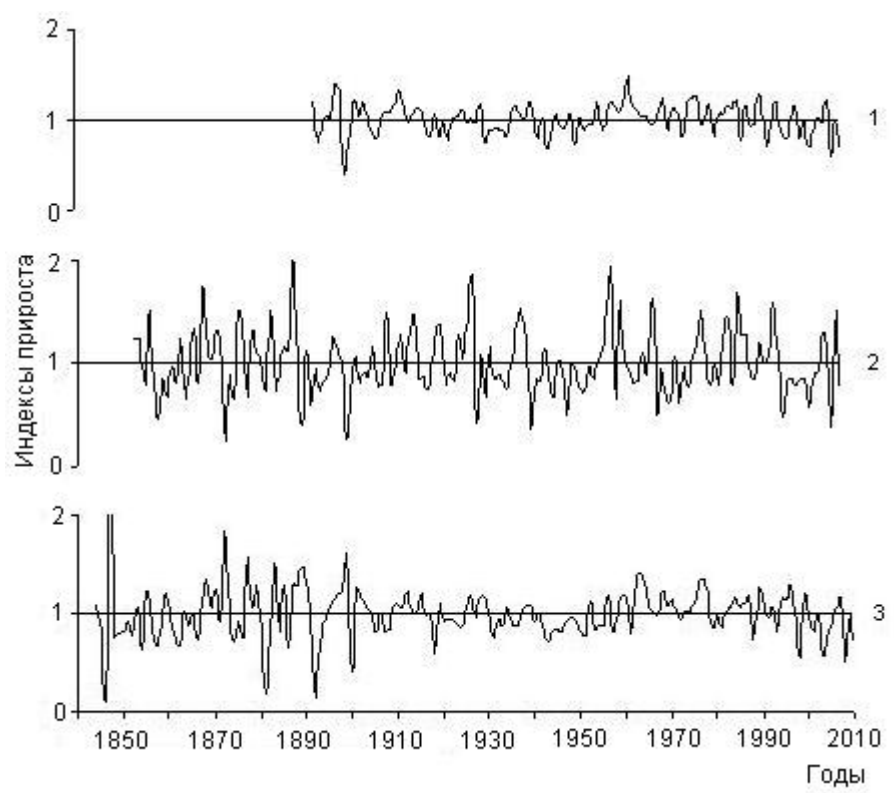

Рис. 4. Хронологии индексов радиального прироста ели (1), лиственницы (2) и кедра (3) в зоне контакта «лес-степь» 
Синхронность серий у ели низкая (59 \%). Значения коэффициента чувствительности серий по ели колеблется от 0,20 до 0,30. Синхронность серий по кедру средняя (68\%), а чувствительность хронологий для различных участков высотного профиля варьирует от 0,27 до 0,29 .

Наибольшая амплитуда колебаний индексов прироста у лиственницы (от 0,25 до $1,91)$, наименьшая - у ели (от 0,60 до 1,49). Кедр по этому показателю занимает промежуточное положение $(0,20-1,84)$. Тренды индексов прироста кедра, лиственницы и ели в период современного потепления (с 1980-х гг.) слабоотрицательные, в то время как в предшествующий ему 30 -летний период - незначительно положительные (рис. 5).

Синхронность в динамике изменений ширины годичных колец, общие периоды понижений и повышений радиального прироста и высокая величина коэффициента чувствительности предполагают достаточно сильное воздействие общего внешнего фактора на рост деревьев ели, лиственницы и кедра. Расчет коэффициентов корреляции между погодичными сериями прироста и рядами климатических переменных с 1965 по 1994 г. показал наличие климатического сигнала в древеснокольцевых хронологиях (рис. 6).

У деревьев в насаждениях нижней части лесного пояса, произрастающих вблизи поймы р. Актру (выровненные условия увлажнения), значимых коэффициентов корреляции радиального прироста с температурами не выявлено. Достоверная положительная связь прироста с осадками обнаружена у лиственницы (коэффициент корреляции составил для августа 0,41$)$ и отрицательная - у ели (для июля - 0,36).

На лесостепной границе статистическая зависимость прироста деревьев кедра и лиственницы от летних температур отрицательная. Наибольшее влияние на прирост кедра оказывают температуры начала и середины вегетационного периода: $-0,47$ для мая, $-0,45$ для июня, $-0,35$ для июля, $-0,58$ для средней температуры с мая по июль. Значение коэффициента корреляции прироста лиственницы
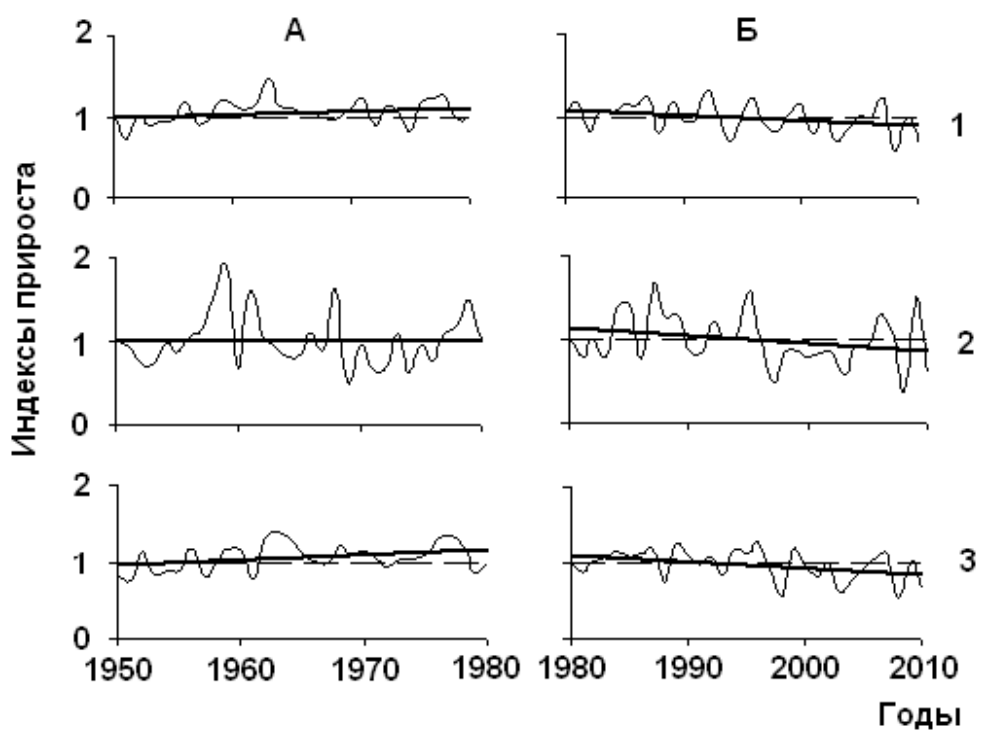

Рис. 5. Индексы радиального прироста ели (1), лиственницы (2) и кедра (3) в 1951-1980 (А) и 1981-2010 гг. (Б). Прямыми линиями показаны линейные тренды изменчивости прироста 
A

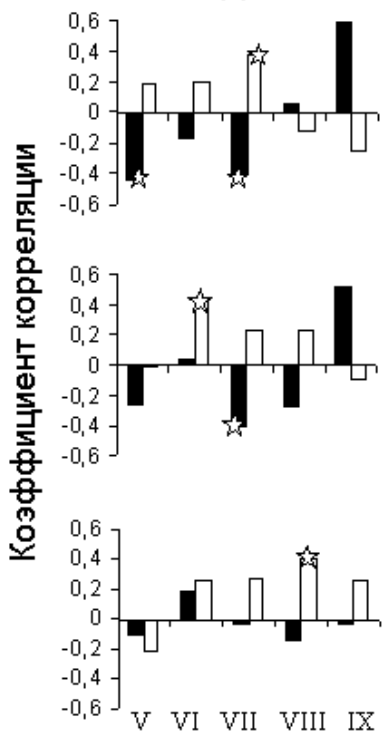

E

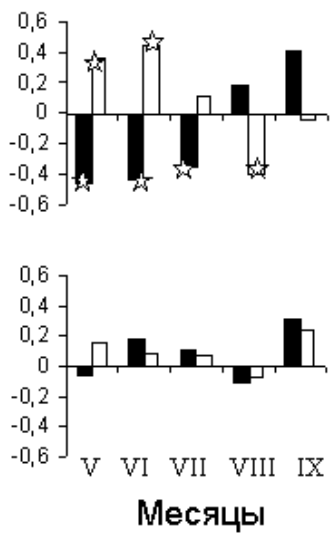

B
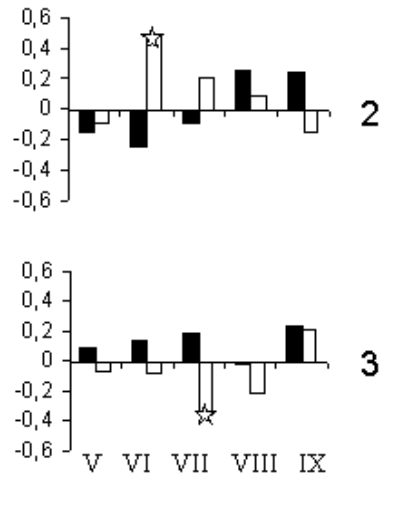

Рис. 6. Коэффициенты корреляции ширины годичных колец лиственницы (А), кедра (Б) и ели (В) в лесостепном экотоне (1), на лесостепной границе (2) и в нижней части лесного пояса (3) со среднемесячными температурами (темные столбцы) и суммами осадков (светлые столбцы) за вегетационный период (звездочками отмечены достоверные значения коэффициентов)

с температурой июля также отрицательно $(-0,41)$. Зависимость радиального прироста от осадков обнаружена у всех пород. Прирост кедра положительно реагирует на весеннелетние осадки (0,36 - для мая, 0,44 - для июня, 0,45 - с суммой осадков с мая по июнь). Прирост лиственницы положительно связан с осадками июня $(0,45)$, с суммами осадков с мая по июнь $(0,46)$ и с мая по июль $(0,36)$. На прирост ели положительное влияние оказывают суммы осадков июня $(0,49)$, с июня по июль $(0,44)$ и с июня по август $(0,37)$.

Прирост деревьев лиственницы, произрастающих в лесостепном экотоне, показал отрицательную зависимость со средними температурами мая и июля $(-0,44$ и $-0,39$ соответственно). Положительная связь прироста обнаружена с суммами осадков июля $(0,37)$ и с июня по июль $(0,40)$.

Таким образом, в контактной зоне леса нижней части лесного пояса Северо-Чуйского хребта и Курайской степи связь радиального прироста хвойных с климатическими переменными оказалась довольно типичной для засушливых территорий: отрицательная с температурой и положительная - с осадками первой половины вегетационного сезона. Причем аналогичная связь выявлена в других лесостепных областях России: в Алтайском крае (Малышева, Быков, 2011a, 2011б), на Южном Урале (Agafonov, Kukarskikh, 2008), в Забайкалье (Глызин и др., 2005) и др. Видимо, механизм влияния циклональной и антициклональной циркуляции атмосферы на радиальный прирост не зависит от видовой принадлежности деревьев, определяет содержание влаги в почве в период интенсивного роста деревьев, действует через их корневую систему. К пространственным или временным различиям в отклике, по всей вероятности, может привести разный микрорельеф территории (ровная или холмистая по- 
верхность), наличие близко расположенного водотока (круглогодичного или временного, сезонного), ветровой режим, особенно в зимнее время, режим снегонакопления, циклы похолодания-потепления или увлажненияиссушения и т.п. Эти факторы действуют, скорее всего, комплексно.

Анализ возрастной структуры древостоев и хода реконструированной температуры воздуха вегетационного сезона за последние 500 лет для верховий р. Актру (Бочаров, 2011б) показал их сопряженную изменчивость.

Появление самых старых деревьев (лиственница I поколения, которая произрастает во всех насаждениях по высотному профилю: нижняя часть лесного пояса, лесостепная граница, лесостепной экотон) происходило в течение XVIII в., что совпадает с вековым циклом повышения температуры. Следующий этап формирования древостоев (II поколение лиственницы в сомкнутом лесу и лесостепном экотоне, І поколение кедра в лесу) произошел в первой половине XIX в. и связан с восходящей ветвью векового цикла потепления. Деревья лиственницы II поколения и кедра I поколения на лесостепной границе, кедра II поколения и ели I и II поколений в сомкнутом лесу появились на рубеже XIX и XX вв., на максимуме векового цикла. Выделенное нами III возрастное поколение в древостоях всех трех пород возникло во второй трети ХX в., что сопряжено с пониженной частью векового цикла или с нисходящей ветвью внутривекового, где температура составляла в среднем около $9{ }^{\circ} \mathrm{C}$. Это значение является климатической нормой для летних месяцев для верховьев р. Актру (Тронов и др., 1965).

В зоне контакта сомкнутого леса нижней части лесного пояса Северо-Чуйского хребта и Курайской степи появление поколений хвойных определяется вековой и внутривековой цикличностью хода температуры.
Возможно, в данном случае имеет значение и цикличность режима увлажнения, которая отмечена при изучении возрастного состава остепненных сосновых редколесий в Забайкалье (Глызин и др., 2005).

Таким образом, несмотря на различную биологию кедра, ели и лиственницы, деревья на лесостепной границе и в лесостепном экотоне сходно реагируют на изменения климатических переменных: увеличением радиального прироста на снижение температуры и увеличение осадков. В большинстве обследованных вдоль высотного профиля лесных участков климат является лимитирующим радиальный прирост фактором. На лесостепных границе и экотоне его действие усиливается. В то же время в нижней части лесного пояса ведущими для радиального прироста хвойных выступают факторы неклиматической природы (фитоценотические).

\section{Заключение}

Таким образом, на основании проведенных исследований структуры хвойных древостоев и радиального прироста хвойных деревьев на нижней ландшафтной и климатической границах их распространения (по высотному профилю: нижняя часть лесного пояса, северный макросклон Северо-Чуйского хребта - лесостепная граница - лесостепной экотон, Курайская степь) (Центральный Алтай) установлено, что структура хвойных древостоев сложная, циклично-разновозрастная, при движении вдоль градиента от леса к степи доля участия кедра и ели в составе насаждений снижается, а лиственницы - увеличивается. В нижней части лесного пояса распространены кедровые леса с участием ели и лиственницы со сложной цикличноразновозрастной структурой, где каждый из видов деревьев представлен тремя возрастными поколениями. Диапазон средних возрастов 
кедра от 60 до 171 года, лиственницы - 53-215 лет, ели - 50-133 года. Лесостепную границу формируют циклично-разновозрастные лиственничные леса с незначительным участием кедра и ели. Они характеризуются тремя поколениями лиственницы с диапазоном их среднего возраста 54-238 лет и одним, реже двумя поколениями кедра и ели с возрастным диапазоном 58-127 и 54-78 лет соответственно. Лесостепной экотон представлен фрагментами чистых лиственничников, состоящих из двух, реже трех возрастных поколений с диапазоном от 69 до 265 лет.

Полученные хронологии радиального прироста ели, кедра и лиственницы хорошо согласуются между собой, но различаются по амплитуде. В современный период инструментально зафиксированного на Алтае потепления климата на лесостепной границе и в лесостепном экотоне радиальный прирост всех трех пород лимитируется недостатком осадков и высокой температурой воздуха в течение вегетационного периода. В нижней части лесного пояса выравненность режима увлажнения нарушает установленные закономерности связи прирост-климат.

Анализ возрастной структуры исследуемых лесов и хода реконструированной температуры воздуха вегетационного сезона показал, что появление поколений хвойных определяется вековой и внутривековой цикличностью термического режима.

\section{Благодарность}

Авторы выражают свою благодарность двум анонимным рецензентам за внимательное и тщательное прочтение статьи и доброжелательную критику.

\section{Список литературы}

Бочаров А.Ю. (2011а) Высокогорные леса Центрального Алтая. Таксачионная структура и радиальный рост. Saarbrucken, LAP Lambert Academic Publishing, 212 c. [Bocharov A.Yu. (2011a) High altitudinal forests in the central Altai Mountains. Taxation structure and ragial growth. Saarbrucken, LAP Lambert Acad. Publ., 212 p. (in Russian)]

Бочаров А.Ю. (2011б) Структура и динамика высокогорных лесов Северо-Чуйского хребта (Горный Алтай) в условиях изменений климата. Вестник Томск. гос. ун-та, 352: 203-206 [Воcharov A.Yu. (2011b) Structure and dynamics of high altitudinal forests on the Severo-Chuisky Range (the Altai Mountains) under climate change. Tomsk State Univ. Journal [Vestnik TGU], 352: 203-206 (in Russian)]

Вахнина И.Л. (2011) Анализ динамики ширины годичных колец сосны обыкновенной в условиях Восточного Забайкалья. Изв. Иркутск. гос. ун-та. Сер. Биология, Экология, 4 (3): $13-$ 17 [Vakhnina I.L. (2011) Analysis of the dynamics of Scots pine tree ring width in the East Transbaikal. The Bulletin of Irkutsk State Univ. Series Biology and Ecology [Izvestiia IrGU. Biologiia, Ekologiia], 4 (3): 13-17 (in Russian)]

Глызин А.В., Размахнина Т.Б., Корсунов В.М. (2005) Дендрохронологические исследования в контактной зоне “лес-степь” как источник информации о ее динамике. Сиб. экол. журн., 12 (1): 79-83 [Glyzin A.V., Razmahnina T.B., Korsunov V.M. Dendrohronological studies in the foreststeppe contact zone as a source of information about its dynamics. Contemp. Probl. Ecol. [Sibirskii ekologicheskii zhurnal], 12 (1): 79-83 (in Russian)]

Магда В.Н., Блок Й., Ойдупаа О.Ч., Ваганов Е.А. (2011) Выделение климатического сигнала на увлажнение из древесно-кольцевых хронологий в горных лесостепях Алтае-Саянского ре- 
гиона. Лесоведение, 1: 28-37 [Magda V.N., Block J., Oydupaa O.Ch., Vaganov E.A. (2011) Extraction of moisture signal from tree-ring chronologies of mountain forest-steppe of the Altai-Sayan Region. Forestry studies [Lesovedenie], 1: 28-37 (in Russian)]

Магда В.Н., Ваганов Е.А. (2006) Климатический отклик прироста деревьев в горных лесостепях Алтае-Саянского региона. Изв. РАН. Сер. геогр., 5: 92-100 [Magda V.N., Vaganov E.A. (2006) Climatic response of tree increment in mountain forest-steppes in Altai-Sayan Region. Region. Res. Rus. [Izvestiia RAN. Geografiia], 5: 92-100 (in Russian)]

Магда В.Н., Зеленова А.В. (2002) Радиальный прирост сосны как индикатор увлажнения в Минусинской котловине. Изв. Русс. геогр. общ-ва, 134 (1): $73-79$ [Magda V.N., Zelenova A.V. (2002) Radial increment in pine as an indicator of humidity in Minusinsk Depression. Izvestiya of Rus. Geogr. Soc. [Izvestiia RGO], 134 (1): 73-79 (in Russian)]

Малышева Н.В., Быков Н.И. (2011а) Дендроклиматический анализ ленточных боров Западной Сибири. Изв. РАН. Сер. геогр., 6: 68-77 [Malysheva N.V., Bykov N.I. (2011a) Dendroclimatic analysis of Western Siberia pine belt forests. Region. Res. Rus. [Izvestiia RAN. Geografiia], 6: 68-77 (in Russian)]

Малышева Н.В, Быков Н.И. (2011б) Дендрохронологические исследования ленточных боров юга Западной Сибири. Барнаул, Азбука, 125 с. [Malysheva N.V., Bykov N.I. (2011b) Dendrochronological investigations of pine forests in southern West Siberia. Barnaul, Azbuka, 125 p. (in Russian)]

Матвеев С.В., Матвеева С.В., Шурыгин Ю.Н. (2012а) Повторяемость сильных засух и многолетняя динамика радиального прироста сосны обыкновенной в Усманском и Хреновском борах Воронежской области. Журн. Сиб. федерал. ун-та. Биология, 5 (1): $27-42$ [Matveev S.V., Matveeva S.V., Shurygin Yu.N. (2012) Recurrence of severe droughts and long-term dynamics of radial increment of the Scots pine in the Usman and Khrenovoe Forests in the Voronezh Region. J. Sib. Federal Univ. Biology, 5 (1): 27-42 (in Russian)]

Матвеев С.М., Таранков В.И., Шурыгин Ю.Н. (2012б) Дендроклиматический анализ естественных и искусственных древостоев сосны обыкновенной Pinus sylvestris L. в свежих лесорастительных условиях Хреновского бора. Науч. журн. КубГАУ, 75(01): 1-12. Адрес доступа: http://ej.kubagro.ru/2012/01/pdf/30.pdf [Matveev S.M., Tarankov V.I., Shurygin Yu.N. (2012b) Dendroclimatological analysis of the natural forest and forest plantations of Scots pine Pinus sylvestris L. in dry-moist site conditions of the Khrenovoe pine forest. Sci. J. Kuban State Agricul. Univ. [Nauchnyi zhurnal KubGAU], 75(01): 1-12. Web-site: http://ej.kubagro.ru/2012/01/pdf/30.pdf (in Russian)]

ОСТ 56-69-83. Площади пробные лесоустроительные. Метод закладки (1984) М., Гослесхоз CCCP, 62 с. [OST 56-69-83. Forest sample areas. Methods of establishment. (1984) Moscow, Gosleskhoz USSR, 62 p. (in Russian)]

Сафонов Д.Н., Гурский А.Ан. (2005) Дендрохронологические исследования в вопросах ведения хозяйства в Бузулукском бору. Изв. Оренбург. гос. аграр. ун-та, 1 (5-1): 96-99 [Safonov D.N., Gursky A.An. (2005) Dendroclimatological investigations in forest management in Buzuluksky Bor. Proceedings of Orenburg State Agrar. Univ. [Izvestiia OrGAU], 1(5-1): 96-99 (in Russian)]

Семечкин И.В. (1970) Динамика возрастной структуры древостоев и методы изучения. Boпросы лесоведения, 1. Красноярск, ИЛиД СО АН СССР, с. 422-445 [Semechkin I.V. (1970) The dynamics of stand age structure and methods of its study. Issues of forest science, 1. Krasnoyarsk, Inst. Forest and Wood SB AN USSR, p. 422-445 (in Russian)]

$$
-439-
$$


Семечкина М.Г. (1964) Пути повышения точности определения возраста кедра в разновозрастных древостоях Западного Саяна. Особенности устройства горных лесов Сибири. М., Наука, 92-102 [Semechkina M.G. (1964) Improvement of accuracy of Siberian stone pine age determination in uneven-aged forests in the western Sayan Mountains. Patterns of inventory of mountain forests in Siberia. Moscow, Nauka, 92-102 (in Russian)]

Тишин Д.В. (2008) Дендроклиматические исследования ели финской (Picea x fennica (Regel) Kom.) на южной границе ареала. Уч. зап. Казанск. гос. ун-та. Естеств. Науки, 150 (4): 219-225 [Tishin D.V. (2008) Dendroclimatic study of Picea x fennica (Regel) Kom. in the southern range limit. Proceedings of Kazan University. Natural Sciences, 150 (4): 219-225 (in Russian)]

Тронов М.В., Тронова Л.Б., Белова Н.И. (1965) Основные черты климата горноледникового бассейна Актру. Гляциология Алтая, 4. Томск, ТГУ, с. 3-49 [Tronov M.V., Tronova L.B., Belova N.I. (1965) Main features of climate in the mountain glacier basin Aktru. Glaciology of the Altai, 4. Tomsk State University, p. 3-49 (in Russian)]

Харламова Н.Ф., Козлова Д.С. (2014) Статистические характеристики режима атмосферных осадков в Алтайском регионе. Изв. Алтай. гос. ун-та, 3-1(83): 145-150 [Kharlamova N.F., Kozlova D.S. (2014) Statistic characteristics of regime of atmospheric precipitation in Altai region. The News of Altai State Univ. [Izvestiia AGU], 150 (4): 219-225 (in Russian)]

Шиятов С.Г. (1986) Дендрохронология верхней гранищы леса на Урале. М., Наука, 136 с. [Shiyatov S.G. (1986) Dendrochronology of upper forest line in the Urals. Moscow, Nauka, 136 p. (in Russian)]

Agafonov L.I., Kukarskikh V.V. (2008) Climate changes in the past century and radial increment of pine in the Southern Ural steppe. Rus. J. Ecol., 39 (3): 160-167.

Cook E.R. (1985) A time series analysis approach to tree-ring standartization: PhD Dissertation. Tuscon, University of Arizona, $171 \mathrm{p}$.

Douglass A.E. (1919) Climatic cycles and tree growth: A study of the annual rings of trees in relation to climate and solar activity. Washington, Carnegie Inst., 1, $127 \mathrm{p}$.

Guiot J. (1986) ARMA techniques for modeling tree-ring response to climate and for reconstructing variations of paleoclimates. Ecol. Model., 33: 149-171.

Holmes R.L. (1983) Computer-assisted quality control in tree-ring dating and measurements. Tree-Ring Bull. 44: 69-75.

Holmes R.L. (1992a) Program COFECHA: Version 3. Tuscon, Laboratory of tree-ring research, University of Arizona.

Holmes R.L. (19926) Program CRONOL. Tuscon, Laboratory of tree-ring research, University of Arizona.

Kucherov S.E. (2010) Reconstruction of summer precipitation in the southern Urals over the last 375 years based on analysis of radial increment in the Siberian larch. Rus. J. Ecol., 41(4): 284-292.

Rinn F. (1996) TSAP V3.5. Computer program for tree-ring analysis and presentation. Heidelberg, Frank Rinn Distribution, 264 p. 